NBER WORKING PAPER SERIES

\title{
STABILIZATION OF EFFECTIVE EXCHANGE RATES UNDER COMMON CURRENCY BASKET SYSTEMS
}

\author{
Eiji Ogawa \\ Junko Shimizu \\ Working Paper 12198 \\ http://www.nber.org/papers/w12198 \\ NATIONAL BUREAU OF ECONOMIC RESEARCH \\ 1050 Massachusetts Avenue \\ Cambridge, MA 02138 \\ April 2006
}

This paper is forthcoming in the Journal of the Japanese and International Economies and it was presented at the 18th Annual TRIO Conference (supported by NBER-TCER-CEPR-CIRJE) held at University of Tokyo on December 9-10, 2005. The authors are grateful to Taizo Motonishi, Mark Spiegel, and participants for their useful suggestion and discussion. The authors are thanks to Takatoshi Ito, John Williamson, Jae-Ha Park and participants in at the International Workshops of RIETI on October 31, 2005 for their useful comments, too. Ogawa: Corresponding author. Graduate School of Commerce and Management, Hitotsubashi University. 2-1 Naka, Kunitachi, Tokyo 186-8601, Japan, Tel: 81-42-580-8859, Fax: 81-42-580-8747, E-mail address: ogawa.eiji@ srv.cc.hit-u.ac.jp. Shimizu: Faculty of Economics, Meikai University. The views expressed herein are those of the author(s) and do not necessarily reflect the views of the National Bureau of Economic Research.

(O2006 by Eiji Ogawa and Junko Shimizu. All rights reserved. Short sections of text, not to exceed two paragraphs, may be quoted without explicit permission provided that full credit, including $\odot$ notice, is given to the source. 
Stabilization of Effective Exchange Rates Under Common Currency Basket Systems

Eiji Ogawa and Junko Shimizu

NBER Working Paper No. 12198

April 2006

JEL No. E6, F3, F4

\begin{abstract}
$\underline{\text { ABSTRACT }}$
We investigate the extent to which a common currency basket peg would stabilize effective exchange rates of East Asian currencies. We use an AMU (Asian Monetary Unit), which is a weighted average of ASEAN10 plus 3 (Japan, China, and Korea) currencies, as a common currency basket to investigate the stabilization effects. We compare our results with another result on stabilization effects of the common G3 currency (the US dollar, the Japanese yen, and the euro) basket in the East Asian countries (Williamson (2005)). We obtained the following results: first, the AMU peg system would be more effective in reducing fluctuations of the effective exchange rates as more countries applied the AMU peg system in East Asia. Second, the AMU peg system would more effectively stabilize the effective exchange rates than a common G-3 currency basket peg system for four (Indonesia, the Philippines, South Korea and Thailand) of the seven countries. The results suggest that the AMU basket peg would be useful for the East Asian countries whose trade weights on Japan are relatively higher than others.
\end{abstract}

\title{
Eiji Ogawa
}

Hitotsubashi University

2-1 Naka, Kunitachi

Tokyo, 186-8601

JAPAN

ogawa.eiji@srv.cc.hit-u.ac.jp

Junko Shimizu

Meikai University

8 Akemi, Urayasu

Chiba, 279-8550

JAPAN

jshimizu@meikai.ac.jp 


\section{Introduction}

A variety of exchange rate systems are found in East Asian countries. The monetary authorities of Japan and Korea are adopting a flexible exchange rate system. On one hand, those of China and Malaysia have been keeping a de facto dollar peg system as shown in Ogawa and Sakane (2006) even though they announced the change in their own exchange rate systems into a managed floating exchange rate system with references with a currency basket on July 21, 2005. East Asian currencies make asymmetric responses to the US dollar depreciation under the variety of exchange rate systems. Moreover, some of the East Asian countries are facing coordination failure in choosing their own exchange rate systems (Ogawa and Ito (2002)) as shown in the fact that the monetary authority of Malaysia followed the announcement of exchange rate system reform by that of China. It is supposed that all of the monetary authorities should adopt the same exchange rate policy, for example, a common currency basket system in order to solve both the asymmetric responses to the US dollar depreciation and the coordination failure among East Asian countries.

If the common currency basket systems are adopted in East Asian countries who have a different structure of trade with the rest of world, effective exchange rates might be more unstable due to different weights on each of foreign currencies between the common currency basket and the effective exchange rate for each of the East Asian currencies. For the reason, it is important to investigate stabilization of effective exchange rate under a common currency basket system because effective exchange rates should have effects on exports and imports, and in turn trade 
balances. In this paper, we suppose an AMU (Asian Monetary Unit), which is a weighted average of ASEAN10 ${ }^{1}$ plus 3 (Japan, China, and Korea) currencies (Ogawa and Shimizu $(2005,2006)$ ), as a common currency basket to investigate the stabilization effects of an AMU peg system on East Asian currencies.

The reminder of this paper consists of the following sections. Section 2 classifies some types of currency basket systems and overviews previous researches about the currency basket system in East Asian countries. Section 3 explains a theoretical model of exchange rate system choice within the regional economies to show that the monetary authorities of East Asian countries should adopt the common currency basket system. In section 4, we briefly describe our method to calculate the AMU as a common currency basket for East Asian countries. Section 5 investigates the stabilization effects of the AMU peg system on effective exchange rates and compares our analytical results with those of Williamson (2005), who showed the effectiveness of the G3 currency (the US dollar, the Japanese yen, and the euro) basket in the East Asian countries. The final section offers concluding remarks.

\section{Currency basket system in East Asia}

2-1. Objectives of a common currency basket peg in East Asia

At first, we discuss about objectives of adopting a currency basket peg in East Asian countries. Intra-regional financial cooperation has been developing in

1 ASEAN10 includes Brunei, Cambodia, Indonesia, Laos, Malaysia, Myanmar, the Philippines, Singapore, Thailand, and Vietnam. 
East Asia since the Asian currency crisis in 1997. In response to closer trade and economic relationships among East Asian countries, it is objectives of regional financial cooperation to prevent another future currency crisis and to strengthen financial systems within the region. Under these circumstances, it is becoming more and more important to coordinate exchange rate policies among the East Asian countries. Currently, many researchers advocate that the monetary authorities of East Asian countries should adopt a currency basket system. This appears to be an appropriate choice after the announcement about its exchange rate system reform made by the Chinese Government on July 21, 2005.

In contrast, previous researches have obtained mixed results about effectiveness of the currency basket peg system for its objectives. Frankel (1999) listed nine currency arrangements, including a currency basket system, and discussed the advantages and disadvantages for each of the arrangements. He concluded that what is an optimal exchange rate system depends on circumstances of a particular country and time and that no single currency regime is the best for all time. He pointed out that there are two advantages of fixing the exchange rate for any country: the first is to reduce foreign exchange transaction costs and foreign exchange rate risks which can discourage international trade and foreign direct investments. The second is to provide a credible nominal anchor for monetary policy. ${ }^{23}$ For the first advantage, there is an argument that foreign exchange rate risks

2 Frankel (1999) indicated that another advantage is to prevent competitive depreciation or competitive appreciation.

3 Apparently, it is an advantage of a floating exchange rate system that the monetary authorities can conduct an independent monetary policy under the system. However, we do not discuss about it because we focus on exchange rate policy in this paper. 
can be hedged by using forward exchange transaction and other instruments. There are costs for hedging, both in terms of bid-ask spread and in terms of a possible exchange risk premium although these are, in general, regarded to be small. Against this view, Rose (2000) argued that it might be much more difficult to hedge foreign exchange rate risks in emerging countries than commonly believed. Rather, a common currency could induce greater financial integration, which then leads to increases in international trade in goods and services. ${ }^{4}$

On the other hand, Yoshino, Kaji and Suzuki (2004) considered three exchange rate regimes, which include the floating, dollar peg, and currency basket peg system, and, on one hand, three policy objectives, which include GDP stability, current account stability, and the exchange rate stability. They defined a loss function for each of the policy objectives to choose the optimal exchange rate system that could minimize the loss function in an economy with exogenous shocks. They concluded that it would not be in general an optimal choice to adopt a currency basket peg with trade weights. ${ }^{5}$

However, it is more important to stabilize exchange rates among the intra-regional currencies because East Asian country economies have closer economic relationships with each other in recent years. Fluctuations of exchange rates of East Asian currencies in terms of major international currencies might cause a large fluctuation of effective exchange rates of the East Asian currencies.

4 Rose (2000) discussed that a monetary union such as the EMU (Economic and Monetary Union) in the EU (European Union) may lead to a large increase in international trade (due to the results of empirical analysis by using gravity model with 186 countries for 5 years spanning 1970 through 1990).

5 In their empirical study, they found that the optimal currency basket weights vary, depending on the policy objectives. 
The fluctuations of effective exchange rates should give a bias to relative competitiveness of the different countries of East Asia and, in turn, disrupt the East Asian economy as a whole. Williamson (2005) proposed a common currency basket composed with three major currencies (G3 currency basket) for East Asian countries. He indicated that a G3 common currency basket peg could prevent the fluctuations in the exchange rates of the East Asian currencies in terms of the major international currencies.

On the other hand, Ogawa and Shimizu (2005, 2006) proposed an Asian Monetary Unit (AMU), as a weighted average of thirteen East Asian (ASEAN10 plus 3) currencies, as a common currency basket in East Asia. In addition, we proposed AMU Deviation Indicators which show a deviation measurement of each East Asian currency from its benchmark level in terms of the AMU. ${ }^{6}$ The AMU Deviation Indicators explicitly shows the current condition of misalignments among the East Asian currencies. We suggested that the deviation measurements are useful as an indicator for surveillance at the ASEAN+3 Finance Deputy Ministers Meeting. ${ }^{7}$

6 The AMU and AMU Deviation Indicators are a joint project of the 21st century COE (Center of Excellence) project of Hitotsubashi University and RIETI (Research Institute of Economy, Trade and Industry). They are updated and uploaded on the website of RIETI (http://www.rieti.go.jp/users/amu/index.html) on a weekly basis. The AMU deviation indicators measure the degree of each currency's exchange rate deviation from the regional average (AMU).

7 Williamson (2005) also suggests a common currency basket as a numeraire. He explains that one of the advantages of a currency basket peg is that it is consistent with a wide range of alternative exchange-rate systems. 


\section{2-2. Classification of the types of currency basket}

Some researchers have advocated desirability of a currency basket system for East Asian countries since the Asian currency crisis. We can find that there are several types of currency basket in their discussion. In this section, we refer the previous researches about the currency basket systems recommended in East Asian countries.

At first, we classify two different types of currency basket. One is a currency basket composed of regional currencies. Their basket weights would reflect the relative economic importance of the countries in the region just like the ECU (European Currency Unit) under the EMS (European Monetary System) during a period from 1979 to 1998. Such a currency basket in East Asia might be called an ACU (Asian Currency Unit) or the AMU. The former is being prepared to create by the ADB (Asian Development Bank) while Ogawa and Shimizu (2005, 2006) created the latter.

The other is a currency basket composed of outside currencies which include the US dollar and the euro. Williamson (1999), Kawai and Takagi (2000), Ogawa and Ito (2002) and others have suggested a G3 currency basket composed of three major currencies, which include the US dollar, the Japanese yen, and the euro. In Kawai and Takagi (2000), they recommend that a G3 currency basket system preserves both flexibility and stability in order to promote international trade, foreign direct investments, and economic developments.

An advantage of a common G3 currency basket system is to reduce fluctuations of intra-regional exchange rates as well as fluctuations of exchange rates against the outside currencies. However, there is a view that a currency 
basket system based on the G3 currencies is asymmetric between Japan and the other East Asian countries. Wang (2002) suggests that a more symmetric approach such as the crusade of a single Asian currency is more appropriate to promote the regional monetary cooperation in East Asia. From a standpoint of a regional monetary cooperation, we propose a currency basket that consists of regional currencies which include the Japanese yen.

There is another issue concerning the composition of the currency basket. The monetary authority can choose a desirable currency basket system between a common currency basket and an individual currency basket. The latter is based on own trade pattern and the former is based on common currency basket weights within the region. Williamson (2005) compared the stabilizing effect on effective exchange rates under both the common currency basket system and the individual currency basket system. He found that the common currency basket was more effective in stabilizing effective exchange rates of East Asian currencies. Rajan (2002) pointed out that the common currency basket system might be favorable because the possibility of a competitive devaluation would exist if the monetary authorities can choose their own individual currency basket.

On one hand, Mori, Kinukawa, Nukaya, and Hashimoto (2002) recommended a two-step approach. The first step is that each of the countries should adopt an individual currency basket system by each country. And then, the second step is that they should move on to a common currency basket. Ngiam and Yuen (2002) recommended a similar approach that is called "Cluster Approach." They pointed out that some different clusters should adopt a common currency at first, and then expand the clusters. Finally, it might be possible to unify those 
clusters so as to have one regional currency.

\section{2-3. Current situation in East Asian countries}

Here, we overview current situation of East Asian currencies and bilateral trade relationships in the region. Figure 1 shows the daily movements of nominal exchange rates of the East Asian currencies vis-à-vis the US dollar during a period from January 2000 to October 2005. We express nominal exchange rates in terms of an index that is equal to 100 on January 3,2000 . It shows that exchange rates of the dollar pegging currencies such as the Chinese yuan and the Malaysian ringgit were stable around 100 while the Indonesian rupiah and the Philippine peso were vulnerable throughout the period. On one hand, figure 2 shows the daily movement of nominal exchange rates of East Asian currencies vis-à-vis the Japanese yen in the same period. It shows that exchange rates of all the East Asian currencies were unstable vis-à-vis the Japanese yen throughout the period.

Table 1 shows standard deviations of the daily nominal exchange rates of East Asian currencies vis-à-vis both the US dollar and the Japanese yen during the period from January 2000 to October 2005. The standard deviations of exchange rates of the dollar pegging currencies were smaller than a unity while those of the Singapore dollar and the Brunei dollar were also around 3.3. On one hand, the standard deviations of all East Asian currencies vis-à-vis the Japanese yen were larger than 4. Especially, the standard deviations of the dollar pegging currencies vis-à-vis the Japanese yen were larger than 5 . These results indicate that the dollar peg system might not be so appropriate from the viewpoint of the stability of their 
exchange rates vis-à-vis the Japanese yen.

Tables 2, 3, and 4 show East Asian countries' bilateral trade weights of imports, exports, and a sum of imports and exports in 2000 and 2004, respectively. Table 4 indicates that the average of intra-regional trade weights (in term of a sum of imports plus exports) of the East Asian countries increased from 48.7 percent in 2000 to 51.0 percent in 2004. Especially, the average of intra-regional import weights has steadily increased to 57.9 percent. Japan was the region's largest trade partner for most of the East Asian countries. However, the trade weights with China have increased recently. Some East Asian countries, such as South Korea and Singapore, had stronger trade relationship with China than Japan in 2004. Furthermore, the average of trade weights of the East Asian countries with the United States was decreased to 12.5 percent, which was even lower than with EU in 2004 .

Tables 5 and 6 indicate the latest actual weights on the three major currencies for each of the East Asian currencies in 2004 and 2005 (until November 11, 2005). We estimated the weights on the US dollar, the euro, and the Japanese yen in a possible currency basket for each of the East Asian countries according to a method of Frankel and Wei (1994).${ }^{8}$ As a result, we can divide twelve East Asian currencies into the following two groups: a group of the currencies who have still kept a strong linkage with the US dollar and the other group of the currencies who have increased their weights on the Japanese yen recently.

8 The log differences of exchange rates of each East Asian currency in terms of the Swiss franc were regressed on log differences of three major currencies in terms of the Swiss franc. This method was conducted by Kawai and Akiyama (2000), Ogawa (2002), and others. 
The former is a group of the dollar pegging currencies. Coefficients on the US dollar were almost unity in the cases of the Chinese yuan and the Malaysian ringgit. In the cases of other minor currencies, such as the Cambodia riel, the Las kip, the Myanmar kyat, and the Vietnamese dong, coefficients on the US dollar were close to unity in 2004. Their weights on the US dollar were still close to unity but have slightly decreased in 2005 due to the announcement of Chinese government's changing its exchange rate system on July 21,2005 . These results indicate that they have still kept their de facto dollar peg system in 2005.

The latter is a group of the currencies who seem to adopt a currency basket system. We obtained the following results of estimated weights in a possible currency basket. In the case of Singapore, their weights on the US dollar, the euro, and the Japanese yen were $0.5787,0.1603$, and 0.2729 , respectively in 2004 , and they have changed to $0.5021,0.1707$, and 0.3926 , respectively in $2005 .{ }^{9}$ In the case of Thailand, the weights on the US dollar, the euro, and the Japanese yen were $0.7272,0.1920$, and 0.1923 , respectively in 2004 , and they have changed to 0.6172 , 0.1301 (insignificant), and 0.3124 , respectively in 2005 . We can find the similar movements in the cases of South Korea, Indonesia, and the Philippines. Even in the case of the Chinese yuan, the weight on the Japanese yen has become significant $(0.0935)$ in 2005.

Accordingly, we obtained the results that the actual exchange rate systems adopted by East Asian countries have basically changed from the dollar peg system or the de facto dollar peg system to more flexible exchange rate systems. However,

9 We can find the almost same movements with the Singapore dollar in the case of Brunei dollar because the monetary authority of Brunei adopts a currency board where the Brunei dollar is pegged to the Singapore dollar. 
the monetary authorities have still the overwhelming weight on the US dollar in a half of the East Asian countries. It is important to consider what factors forced the East Asian currencies to keep the strong linkages with the US dollar. We can point out some factors, which include the US dollar as a nominal anchor, appreciation of the Japanese yen against the US dollar, and coordination failure in choosing exchange rate system under intra-regional trade competition. We will focus on the coordination failure among the factors and discuss in the next section.

\section{Common currency basket as a solution for coordination failure in choosing exchange rate systems}

Ogawa and Ito (2002) pointed out that the monetary authorities of Eat Asian countries might have been forced to keep a de facto dollar peg system instead of adopting a desirable exchange rate system such as a currency basket system, even if they find that they would be better-off by adopting it rather than a dollar peg system, ${ }^{10}$ according to lessons they learned from the Asian currency crisis in 1997. The situation can be described as a kind of coordination failure. Suppose that all East Asian countries have been adopting the de facto dollar peg system at the present time and that each of them knows that it should adopt an optimal currency basket system, for example, to stabilize fluctuations of its trade balances with an internationally diversified trading structure.

Suppose that one country switches from the dollar peg system to a currency basket system while the others keep the dollar peg system. The country with a

10 Bénassy-Quéré (1999) and Ohno (1999) analyzed that East Asian currencies were pegged to the US dollar as a coordination failure in choosing exchange rate policies. 
currency basket system, say, country A, might be faced with an increase in fluctuations in trade balances. If the US dollar depreciates against the Japanese yen, the real effective appreciation of country A's currency against the other currencies that are pegged to the US dollar worsens the price competitiveness of exporting firms of country A. On the other hand, if the US dollar appreciates against the Japanese yen, the real effective depreciation of country A's currency against the other currencies improves the price competitiveness of exporting firms of country A. Thus, the country that adopted a currency basket system alone is faced with an increase in the degree of fluctuations of trade balances. Therefore, the monetary authorities of country A are induced to keep the dollar peg system. Similarly, each of the monetary authorities rationally keeps the dollar peg system if they cannot make a coordinated decision but a sequential unilateral decision.

Thus, each of the monetary authorities will keep pegging their home currencies to the US dollar if their trade balances fluctuate more widely in the case of unilaterally pegging its currency to an optimal currency basket peg. When this is the case, they are faced with coordination failure in that they are forced to adopt the dollar peg even though the optimal currency basket peg, if jointly adopted, will minimize the fluctuations in trade balances. Only when both monetary authorities coordinated with each other to adopt the optimal currency basket peg simultaneously can they peg their home currencies to the optimal currency basket.

Suppose that risk-averse monetary authorities choose their exchange rate system under uncertainty; then the monetary authorities are more likely to be faced with coordination failure. Risk-averse monetary authorities, who have a usual utility function with diminishing marginal utility, place a heavier weight on 
increase in their utility of loss caused by exchange rate fluctuations than on decrease in their utility of loss even though they expect that the expected losses are the same. Suppose that the risk-averse monetary authorities of one country shift from the de facto dollar peg system to an optimal currency basket system while the monetary authorities of other countries keep the de facto dollar peg system. The currency would appreciate against the neighbors' currencies if the US dollar depreciated against the Japanese yen, while it would depreciate against the neighbors' currencies if the US dollar appreciated against the Japanese yen. Because risk-averse monetary authorities place a heavier weight on increases in loss caused by shifting their exchange rate system, they tend to hesitate to shift to the optimal currency basket system. Therefore, under such uncertainty, risk-averse monetary authorities tend to take the strategy of wait and see vis-à-vis behavior of the other.

If all of the monetary authorities are risk averse, they cannot help but choose to keep the dollar peg system, which is Nash equilibrium, although they should know that there is a cooperative solution that is superior to a Nash equilibrium. Coordination among some of the monetary authorities of the East Asian countries is necessary for shifting from a situation of the Nash equilibrium to a cooperative solution. The monetary authorities should implement regional coordination for exchange rate arrangements or exchange rate policies.

One way to implement regional coordination is by making all the monetary authorities in the region agree on an arrangement to create a common currency unit that consists of a currency basket. They might make a commitment to follow the common currency value in conducting their exchange rate policy. It is necessary to 
create a common currency basket as a common currency unit that monetary authorities of East Asian countries should refer to when they conduct their exchange rate policies with regional coordination.

Such regional currency arrangements would help to prevent competitive devaluation among the related currencies in a region as well as to solve coordination failure. If the monetary authorities of a country devalue its home currency, the devaluation worsens the price competitiveness of products made in neighboring countries. For that reason, the monetary authorities of the other countries would find it attractive to devalue their home currency, following the first country's devaluation. The regional currency arrangements under which the monetary authorities in the region make a commitment to a coordinated exchange rate policy would prevent a possible competitive devaluation as well as the inertia problem that causes coordination failure.

In addition, regional currency arrangements to keep the exchange rate linked to a common currency basket will help prevent competitive devaluation among the currencies in a region because the monetary authorities have a commitment to the arrangements.

Under a common currency basket system, the monetary authorities in the region should peg or target their home currencies to a common basket currency. In a rigid system where the monetary authorities peg their home currencies to a common basket currency, the currencies in the region are pegged with each other. In a more flexible system where they target their home currencies within a band around a central parity rate vis-à-vis the common basket currency, the currencies are linked to each other within a band. Thus, if they adopted a common basket 
currency system, their currencies would be linked with each other at a parity rate or within a band around a central parity rate.

It is more tractable for the monetary authorities to link their home currencies to a common currency unit that is equivalent to the common basket currency. A common currency unit should be composed of major trader partners on which major weight is placed in calculating an effective exchange rate. They should include the US dollar and the euro as well as the intra-regional currencies which include the Japanese yen from the viewpoint of international trade. ${ }^{11}$

The EU countries adopted the EMS where their home currencies were linked to a common currency unit, the ECU, during the period 1979-1998. The ECU was composed of only the currencies of the EMS member countries. Their currencies were linked to the ECU with a band while the ECU was floating against the other currencies that included the US dollar and the Japanese yen. The monetary authorities had the obligation to intervene in the foreign exchange markets to keep the exchange rates of the currency in the region against the other EMS currencies within a band.

One method to adopt a common basket currency system is for the monetary authorities to create a common currency unit, which consists of currencies of the member countries like the ECU, and link their currencies to the common currency unit. Moreover, also a value of the common currency unit against the US dollar and the euro might be stable if they make coordination to try to stabilize their own home currencies to the two currencies.

11 Kim, Ryou, and Wang (2000) suggested that the Asian currency unit was composed of only the East Asian currencies including the Japanese yen. 


\section{Calculating the value of the AMU}

In this section, we explain our method to calculate the AMU. ${ }^{12}$ We calculate the AMU as a weighted average of East Asian currencies following the method that was used to calculate the ECU. We use the ASEAN10 plus 3 currencies to calculate the AMU. ${ }^{1314}$ As we showed in Section 2, Japan is the region's largest trade partner for most of the East Asian countries and the exchange rates vis-à-vis the Japanese yen have a large impact on their trade accounts. Furthermore, Japan should play an important role to enhance the coordinated exchange rate policies under recent movements of regional economic cooperation in East Asia. Accordingly, we suppose that the Japanese yen should be included in the composition currency of the AMU.

The weight of each currency in the basket is based on an arithmetical average of share in regional GDP measured at PPP (Purchasing Power Parity) and trade volume share (the sum of exports and imports) in the last three years in order to reflect the latest trade relationships and economic size of the thirteen East Asian

12 The CMI (Chiang Mai Initiative) calls on the region's monetary authorities to develop effective regional surveillance capabilities in order to enhance ASEAN+3 economic surveillance. We suggest the importance to monitor the exchange rate and propose a possible way of calculating an AMU and AMU Deviation Indicators as a surveillance indicator. These should help to coordinate exchange rate policies in East Asia, thereby enhancing the monetary authorities' surveillance capabilities. Please see the details about AMU deviation Indicators in Ogawa and Shimizu (2005, 2006).

13 See the details of methodology to calculate the AMU to Ogawa and Shimizu (2005).

14 It is controversial whether Japan should be included or not into the AMU. Kawasaki and Ogawa (2006) analyzed the Optimum Currency Area (OCA) in East Asia empirically to conclude that it is difficult for all of the East Asian countries which include Japan to make OCA for the moment. 
countries for calculation of the AMU. ${ }^{15}$ We quote the value of the AMU in terms of a trade weighted average of the US dollar and the euro (US\$-euro) because both the United States and the euro area countries are important trading partners for East Asia. We use a weight of $65 \%$ for the US dollar and of $35 \%$ for the euro. ${ }^{16}$

Then we choose a benchmark period in order to calculate the AMU Deviation Indicators based on the following criterion: the total trade balance of member countries, the total trade balance of member countries (excluding Japan) with Japan, and the total trade balance of member countries with the rest of world should be close to zero. Table 7, which shows the trade accounts of the thirteen East Asian countries from 1990 to 2003, indicates that the trade accounts were closest to balance in 2001. Assuming a one-year time lag before changes in exchange rates affect trade volumes, we should choose two years of 2000 and 2001 as the benchmark period. ${ }^{17}$ We define the exchange rate of each East Asian currency in terms of the AMU during the benchmark period as the benchmark exchange rate. Table 8 shows the AMU weights as well as trade volumes, GDP measured at PPP,

15 We should consider not only the trade accounts but also capital accounts, especially foreign direct investments (FDI) to choose the currency basket weights. However, it is for the moment unnecessary to take into account capital accounts in choosing the currency basket weights because some East Asian countries have still strict capital controls. On the other hand, Ogawa and Shimizu (2005) tried to use international reserve as an indicator of basket weights to calculate the AMU based on the basket weights of International reserve. In this case, the weights of the Japanese yen and the Chinese yuan in the currency basket are 39.59 percent and 27.41 percent, respectively.

16 These weights were calculated by the average trade volume share of all sampled East Asian countries vis-à-vis the US and the euro area for 2001-2003.

17 For the benchmark period, the exchange rate of the AMU in terms of the US $\$$-euro is set at unity. 
arithmetical average of shares, and the benchmark exchange rates. By using the AMU weights, we calculate the nominal exchange rate of the AMU in terms of the US\$-euro as the weighted sum of each country's US\$-euro exchange rate.

Figure 3 shows the daily movements of the AMU in terms of the US\$-euro. For reference, we add the daily movements of the AMU in terms of the US dollar and the euro. Figure 4 shows daily movements in exchange rates of the East Asian currencies vis-à-vis the AMU. ${ }^{18}$ In the next section, we will use these exchange rates to simulate the nominal effective exchange rates of East Asian countries.

\section{The stabilization effects on the effective exchange rates under the AMU}

In this section, we investigate the stabilization effects of the AMU peg system on the effective exchange rates of the East Asian currencies. We compare the stability of the Ease Asian currencies in terms of nominal effective exchange rates under several currency peg systems because we regard that the stability of nominal effective exchange rate leads to the stability of real effective exchange rate in most of the East Asian countries except for some high-inflation countries such as Indonesia. ${ }^{19}$

18 We set the exchange rate indexes equal to 100 in January 3, 2000.

19 Williamson (2005) also used the nominal effective exchange rate. He explained that the difference between a nominal and a real effective exchange rate is simply the weighted average inflation rate in the countries whose currencies are in the effective exchange rate and that there are no major countries with high inflation rates at the present time. However, Kawai and Takagi (2000) indicated that stability of the real effective exchange rate is important for macroeconomic stability in the East Asian countries. 
As McKinnon (2002) emphasized, a major objective of adopting a common currency peg within a region is an insulation effect of the trading relationship of the region from the disturbances of outside currencies. In other words, a common currency peg guarantees that any changes in exchange rates against third-countries such as the US dollar and the euro would never disturb the trading relationships among the East Asian countries themselves. However, Williamson (2005) examined whether use of a common currency basket would provide adequate stability of effective exchange rate of the participating country currencies. Furthermore, he examined two different types of currency basket peg. One is the currency basket which is composed by all major trading partners and other is the currency basket which is composed by currencies of the outside trading partners. In practice, the former type includes other East Asian currencies and based on its own trade pattern. On one hand, the latter type uses a common currency basket of outside currencies, such as the US dollar, the euro, and the Japanese yen. We call the latter type of currency basket as a common G3 currency basket in order to distinguish it from the AMU. Alternatives of currency basket weights are shown in table 9 .

According to the empirical analysis in Williamson (2005), we simulate how the effective exchange rates would have moved under the alternative exchange rate systems by using the daily exchange rate changes during a past period. Williamson applied two exchange rate systems, which include an individual currency basket peg system and a common G3 currency basket peg system. In addition to his results, we simulate the effective exchange rates under the AMU peg system by using exchange rates of the East Asian currencies vis-à-vis the AMU.

Furthermore, we suppose three different cases under the AMU peg system in 
the region. ${ }^{20}$ The first is the case where only one country adopts the AMU peg system. The second is the case where ASEAN countries adopt the AMU peg system. The third is the case where all of the AMU participating countries adopt the AMU peg system. In order to compare the results with each other, we choose the same East Asian currencies and use the same basket weights as Williamson (2005) calculated each nominal effective exchange rate in his analysis.

Table 10 shows the analytical results. The first column shows the standard deviation of nominal effective exchange rates of the seven East Asian currencies calculated from the actual historical data. These were calculated by the standard deviations of period end monthly nominal effective exchange rates from the International Financial Statistics of the IMF. ${ }^{21}$ The second column shows the results under an individual country basket peg system. ${ }^{22}$ The third column shows the results under a common G3 currency basket peg system. ${ }^{23}$ The forth column,

20 As Williamson (2005) noted, we assume that countries have a rigid peg to their basket so that the exchange rates of participating currencies were always equal to their central rates in order to make these simulation.

21 By way of exception, effective exchange rate data for Indonesia are from Thomson Datastream Series JPMIDNB. Data for South Korea and Thailand real effective exchange rates are from the Citibank CTERI database (Williamson, 2005).

22 Nominal effective exchange rates with individual-country pegs are calculated as follows: The weights shown in table 9 , column 1 , were used to calculate what the US dollar exchange rate (local currency/US dollar) would have been. Actual exchange rates against the US dollar were used to derive other hypothetical rates. These were combined with the trade weights to estimate a hypothetical time path for the nominal effective exchange rates (Williamson (2005)).

23 Common basket pegs composed by G3 currencies are calculated using 1999 as the base year (1US dollar=0.9363euro and 1US dollar $=113.91$ yen), with the weights of dollar, euro and yen composition of 40.2, 31.6, and 28.2 respectively. From these, the 
which is added to the results of Williamson (2005), shows the results under the AMU peg system. ${ }^{24}$

As a whole, the AMU peg system would have stabilized the effective exchange rates in all of the sampled countries. The results indicate that the AMU peg system can reduce fluctuations of their effective exchange rates by reducing instability of intra-regional exchange rates. Furthermore, the AMU peg system would be more effective in reducing the instability of effective exchange rates as the number of country who applies the AMU peg system increases. On one hand, comparing the common G3 currency basket peg system, the AMU peg system would have led to more stability than a common G3 currency basket peg system in four (Indonesia, the Philippines, South Korea and Thailand) of the seven cases. We suppose that the AMU peg system is effective in stabilizing home currencies for the countries whose trade weights on Japan are relatively higher.

\section{Conclusion}

We investigated the stabilizing effects of a common currency basket system on effective exchange rates of the East Asian currencies. In this paper, we suppose the AMU as a common currency basket to investigate whether the AMU peg system

local currency/US dollar, euro, and yen implied by the basket composition and dollar/euro/yen exchange rates are calculated. These are weighted by the individual-country trade weights to yield the nominal effective exchange rates with the common basket peg (Williamson (2005)).

${ }^{24}$ We calculate each country's nominal effective exchange rates by using the exchange rate data of the US dollar, the euro, and the East Asian currencies vis-à-vis the AMU with the same weights of own basket in table 9, column 1 . 
would provide the stability of their effective exchange rates.

As we overviewed in Section 2, we found that the actual exchange rate systems adopted by East Asian countries have basically changed from the US dollar peg to more flexible exchange rate system. The movements make a variety of exchange rate systems among East Asian countries. However, the East Asian currencies have still an overwhelming weight on the US dollar. A common currency basket peg would contribute to stability of the intra-regional exchange rates. As many previous researches showed, there are several types of currency basket, such as a currency basket composed by outsiders' currencies (the US dollar and the euro) and a currency basket composed by intra-regional currencies (AMU).

In this paper, we investigate the stabilization effects of an AMU peg system on East Asian currencies. We compare our analytical results with stabilization effects of a common G3 currency basket peg system, which shown in Williamson (2005). We obtained the following results. First, the AMU peg system is more effective in reducing fluctuations of the effective exchange rates of East Asian currencies as a number of East Asian countries adopted the AMU peg system increases. Second, the AMU peg system stabilizes the effective exchange rates more effectively for Indonesia, the Philippines, South Korea, and Thailand than a common G3 currency basket peg system. These results suggest that the AMU peg system is effective in stabilizing home currencies for the countries whose trade weights on Japan are relatively higher.

In order to simulate the effective exchange rates, we assume that the monetary authorities of the East Asian countries have a rigid peg to their currency baskets so that the exchange rates of participating currencies were always equal to 
their central rate. More practically, we can assume more flexible system where the monetary authorities adopt a common currency peg with a band. We will resolve this point in our further research.

In addition, it is difficult for us to deny that our analysis about the effect of a common currency basket peg is backward-looking in a sense that we used the historical data to simulate the effect of the common currency basket systems on the effective exchange rates. Macroeconomic variables might be changed in the presence of a common currency basket system comparing with the current exchange rate systems. Furthermore, the monetary authorities might change their monetary policy if they adopted a common currency basket peg. If monetary policy is used to maintain the currency within the band of BBC (Basket, Band, and Crawling), GDP and other macro economic variables may change. We will take into account any effects of a common currency basket peg on a convergence of interest rates within the region, macro economic variables, and the monetary policy operation in the near future in order to a possible total effect of a common currency basket. 


\section{References:}

Bénassy-Quéré Agnes, 1999, "Optimal Pegs for East Asian Currencies," Journal of the Japanese and International Economies, Vol. 13: pp.44-60.

Frankel, Jeffrey A. and Shang-Jin Wei, 1994, "Yen Bloc or Dollar Bloc? Exchange Rate Policies of the East Asian Economies," in Takatoshi Ito and Anne O. Krueger, eds., Macroeconomic Linkage: Savings, Exchange Rates, and Capital Flows, Chicago, University of Chicago Press, pp.295-355.

Frankel, Jeffrey A., 1999, "No Single Currency Regime is Right for All Countries or at All Times," NBER Working Paper No.7338.

Kawai, Masahiro and Shigeru Akiyama, 2000, "Implications of the Currency Crisis for Exchange Rate Arrangements in Emerging East Asia”, Policy research Working Paper, No. 2502, World Bank: Washington, DC.

Kawai, Masahiro and Shinji Takagi, 2000, "Proposed Strategy for a Regional Exchange Rate Arrangement in Post-crisis East Asia," World Bank Policy Research Working Paper No.2503.

Kawasaki, Kentaro and Eiji Ogawa, 2006, "What Should the Weights of the Three Major Currencies be in a Common Currency Basket in East Asia?" Asian Economic Journal, forthcoming.

Kim, Tae-Jun, Jai-Won Ryou, and Yunjong Wang. 2000, Regional Arrangements to Borrow: A Scheme for Preventing Future Asian Liquidity Crises. Seoul: Korea Institute for International Economic Policy.

McKinnon, Ronald I., 2002, "After the Crisis, the East Asian Dollar Standard Resurrected," In Monetary and Financial Management in the 21th Century, ed. A.H.H. Tan, Singapore: Would Scientific Publishing Co.

Mori, Junichi, Naoyuki Kinukawa, Hedeki Nukaya and Masashi Hashimoto, 2002, "Integration of the East Asian Economies and a Step by Step Approach towards a Currency Basket Regime," IIMA Research Report No. 2, Institute for International 
Monetary Affairs.

Ngiam, Kee Jin and Hasel Yuen, 2002, "Monetary Cooperation in East Asia: A way forward," presented in an International Seminar "Promoting Growth and Welfare: Structural Changes and the Role of Institutions in Asia", in Santiago, Chili and Rio de Janeiro, Brazil, April 29 - May 03, 2002.

Ogawa, Eiji, 2002, "Should East Asian Countries Return to a Dollar Peg Again?" in Peter Drysdale and Kenichi Ishigaki eds. East Asian Trade and Financial Integration: New ISsues, Asia Pacific Press, pp.159-184.

Ogawa, Eiji and Takatoshi Ito, 2002, "On the Desirability of a Regional Basket Currency Arrangement," Journal of Japanese and International Economies, Vol.16: pp.317-334.

Ogawa, Eiji and Michiru Sakane, 2006, "The Chinese Yuan after the Chinese Exchange Rate System Reform," RIETI Discussion Paper, 06-E-019.

Ogawa, Eiji and Junko Shimizu, 2005, "AMU Deviation Indicator for Coordinated Exchange Rate Policies in East Asia,” RIETI Discussion Paper, 05-E-017.

Ogawa, Eiji and Junko Shimizu, 2006, "AMU Deviation Indicator for Coordinated Exchange Rate Policies in East Asia and its Relation with Effective Exchange Rates," RIETI Discussion Paper, 06-E-002.

Ohno, Kenichi, 1999, "Exchange Rate Management in Developing Asia: Reassessment of the Pre-crisis Soft Dollar Zone," ADB Institute, Working Paper Series, No. 1.

Rajan, Ramkishen S., 2002, "Exchange Rate Policy Options for Post-crisis Southeast Asia: Is There a Case for Currency Baskets?" The World Economy 25: pp.137-163.

Rose, Audrew K., 2000, "One Money, One Market: Estimating the Effect of Common Currencies on Trade," NBER Working Paper No.7432. 
Wang, Tongsan, 2002, "Policy Recommendations on How to Strengthen Financial Cooperation in Asia," Institute for International Monetary Affairs, ed., Report on the Study Group on Strengthening Financial Cooperation and Surveillance, pp. 198-211.

Williamson, John, 2005, “A currency Basket for East Asia, Not Just China,” Policy Briefs in International Economics, No.PB05-1, Institute for International Economics.

Yoshino, Naoyuki, Sahoko Kaji and Ayako Suzuki, 2004, "The Basket-peg, Dollar-peg, and Floating: A Comparative Analysis," Journal of the Japanese and International Economies, Vol.18: pp.183-217. 
Table 1.

The Standard Deviation of the Nominal Exchange rates vis-à-vis the US dollar and the Japanese yen (Jan 2000-Oct 2005)

\begin{tabular}{|c|c|c|c|c|c|c|c|c|c|c|c|c|c|}
\hline vis-à-vis & Brunei\$ & $\begin{array}{c}\text { Cambodia } \\
\text { riel }\end{array}$ & $\begin{array}{c}\text { Chinese } \\
\text { ynan }\end{array}$ & $\begin{array}{c}\text { Indonesian } \\
\text { rupiah }\end{array}$ & $\begin{array}{c}\text { Japanese } \\
\text { yen }\end{array}$ & $\begin{array}{c}\text { South } \\
\text { Korean } \\
\text { won } \\
\end{array}$ & Laos kip & $\begin{array}{c}\text { Malaysian } \\
\text { ringgit }\end{array}$ & $\begin{array}{c}\text { Myanmar } \\
\text { kyat }\end{array}$ & $\begin{array}{l}\text { Philippine } \\
\text { peso }\end{array}$ & $\begin{array}{c}\text { Singapore } \\
\$\end{array}$ & Thai baht & $\begin{array}{l}\text { Vietnamese } \\
\text { dong }\end{array}$ \\
\hline the US dollar & 3.3095 & 2.4634 & 0.4968 & 12.0070 & 7.7533 & 8.0124 & 12.6017 & 0.2148 & 2.9470 & 10.7461 & 3.3055 & 5.7297 & 4.2340 \\
\hline the Japanese yen & 4.0213 & 7.0774 & 5.9416 & 9.7431 & - & 4.3853 & 14.7617 & 5.9454 & 5.2879 & 12.5013 & 4.0218 & 4.0582 & 7.6960 \\
\hline
\end{tabular}

Calculated by authors. All exchange rate data are from Datastream.

Table 2.

Trade weight of East Asian countries (Exports)

\begin{tabular}{|c|c|c|c|c|c|c|}
\hline 2000 & ASEAN10+3 & Japan & China & United States & EU & $\begin{array}{c}\text { rest of the } \\
\text { world }\end{array}$ \\
\hline$\overline{\text { Brunei Darussalam }}$ & $78.5 \%$ & $40.7 \%$ & $1.8 \%$ & $12.0 \%$ & $3.6 \%$ & $5.9 \%$ \\
\hline Cambodia & $9.9 \%$ & $1.0 \%$ & $2.1 \%$ & $65.9 \%$ & $20.6 \%$ & $3.6 \%$ \\
\hline China,P.R.: Mainland & $28.2 \%$ & $16.7 \%$ & - & $20.9 \%$ & $16.4 \%$ & $34.5 \%$ \\
\hline Indonesia & $52.1 \%$ & $23.2 \%$ & $4.5 \%$ & $13.7 \%$ & $14.3 \%$ & $19.9 \%$ \\
\hline Japan & $27.1 \%$ & - & $6.3 \%$ & $30.1 \%$ & $16.8 \%$ & $25.9 \%$ \\
\hline South Korea & $34.4 \%$ & $11.9 \%$ & $10.7 \%$ & $22.0 \%$ & $14.4 \%$ & $29.2 \%$ \\
\hline Lao People's Dem.Rer & $47.1 \%$ & $2.8 \%$ & $1.5 \%$ & $2.3 \%$ & $26.2 \%$ & $24.4 \%$ \\
\hline Malaysia & $46.0 \%$ & $13.0 \%$ & $3.1 \%$ & $20.5 \%$ & $14.0 \%$ & $19.5 \%$ \\
\hline Myanmar & $33.6 \%$ & $5.5 \%$ & $5.7 \%$ & $22.4 \%$ & $16.7 \%$ & $27.4 \%$ \\
\hline Philippines & $35.1 \%$ & $14.7 \%$ & $1.7 \%$ & $29.9 \%$ & $18.1 \%$ & $16.9 \%$ \\
\hline Singapore & $42.4 \%$ & $7.5 \%$ & $3.9 \%$ & $17.3 \%$ & $14.0 \%$ & $26.3 \%$ \\
\hline Thailand & $40.0 \%$ & $14.7 \%$ & $4.1 \%$ & $21.3 \%$ & $16.3 \%$ & $22.4 \%$ \\
\hline Vietnam & $48.9 \%$ & $17.8 \%$ & $10.6 \%$ & $5.1 \%$ & $20.5 \%$ & $25.5 \%$ \\
\hline Average & $40.3 \%$ & $14.1 \%$ & $4.7 \%$ & $21.8 \%$ & $16.3 \%$ & $21.7 \%$ \\
\hline 2004 & ASEAN10+3 & Japan & China & United States & EU & $\begin{array}{c}\text { rest of the } \\
\text { world }\end{array}$ \\
\hline$\overline{\text { Brunei Darussalam }}$ & $73.9 \%$ & $38.1 \%$ & $4.5 \%$ & $8.6 \%$ & $2.6 \%$ & $14.9 \%$ \\
\hline Cambodia & $12.3 \%$ & $3.5 \%$ & $1.0 \%$ & $55.9 \%$ & $25.9 \%$ & $6.0 \%$ \\
\hline China,P.R.: Mainland & $24.3 \%$ & $12.4 \%$ & - & $21.1 \%$ & $18.1 \%$ & $36.5 \%$ \\
\hline Indonesia & $53.7 \%$ & $22.3 \%$ & $6.4 \%$ & $12.3 \%$ & $12.6 \%$ & $21.4 \%$ \\
\hline Japan & $33.8 \%$ & - & $13.1 \%$ & $22.7 \%$ & $15.8 \%$ & $27.7 \%$ \\
\hline South Korea & $37.7 \%$ & $8.6 \%$ & $19.7 \%$ & $17.0 \%$ & $15.0 \%$ & $30.3 \%$ \\
\hline Lao People's Dem.Rer & $36.6 \%$ & $1.3 \%$ & $2.1 \%$ & $0.6 \%$ & $28.6 \%$ & $34.3 \%$ \\
\hline Malaysia & $45.4 \%$ & $10.1 \%$ & $6.7 \%$ & $18.8 \%$ & $12.6 \%$ & $23.3 \%$ \\
\hline Myanmar & $56.5 \%$ & $5.3 \%$ & $6.0 \%$ & $0.0 \%$ & $16.1 \%$ & $27.4 \%$ \\
\hline Philippines & $46.9 \%$ & $20.1 \%$ & $6.7 \%$ & $18.2 \%$ & $17.2 \%$ & $17.8 \%$ \\
\hline Singapore & $43.5 \%$ & $6.4 \%$ & $8.6 \%$ & $13.0 \%$ & $14.5 \%$ & $29.1 \%$ \\
\hline Thailand & $44.8 \%$ & $13.9 \%$ & $7.3 \%$ & $15.9 \%$ & $14.7 \%$ & $24.6 \%$ \\
\hline Vietnam & $38.1 \%$ & $13.6 \%$ & $9.0 \%$ & $20.2 \%$ & $23.6 \%$ & $18.2 \%$ \\
\hline Average & $42.1 \%$ & $13.0 \%$ & $7.6 \%$ & $17.3 \%$ & $16.7 \%$ & $23.9 \%$ \\
\hline
\end{tabular}

Source: DOTS of IMF (Nov. 2005)

ASEAN 10+ 3 includes ASEAN 10 countries plus South Korea, China and Japan. 
Table 3.

Trade weight of East Asian countries (Imports)

\begin{tabular}{|c|c|c|c|c|c|c|}
\hline 2000 & ASEAN10+3 & Japan & China & United States & EU & $\begin{array}{l}\text { rest of the } \\
\text { world }\end{array}$ \\
\hline Brunei Darussalam & $264.7 \%$ & $4.7 \%$ & $1.2 \%$ & $10.8 \%$ & $15.8 \%$ & $8.8 \%$ \\
\hline Cambodia & $56.3 \%$ & $4.1 \%$ & $7.9 \%$ & $2.3 \%$ & $6.6 \%$ & $34.8 \%$ \\
\hline China,P.R.: Mainland & $38.6 \%$ & $18.4 \%$ & - & $9.9 \%$ & $13.6 \%$ & $37.8 \%$ \\
\hline Indonesia & $47.7 \%$ & $16.1 \%$ & $6.0 \%$ & $10.1 \%$ & $12.5 \%$ & $29.6 \%$ \\
\hline Japan & $35.6 \%$ & - & $14.5 \%$ & $19.1 \%$ & $12.6 \%$ & $32.7 \%$ \\
\hline South Korea & $39.1 \%$ & $19.8 \%$ & $8.0 \%$ & $18.2 \%$ & $10.1 \%$ & $32.5 \%$ \\
\hline Lao People's Dem.Rer & $87.3 \%$ & $3.4 \%$ & $5.5 \%$ & $0.7 \%$ & $6.5 \%$ & $5.5 \%$ \\
\hline Malaysia & $53.5 \%$ & $21.1 \%$ & $3.9 \%$ & $16.6 \%$ & $11.0 \%$ & $18.8 \%$ \\
\hline Myanmar & $80.8 \%$ & $7.1 \%$ & $18.0 \%$ & $0.6 \%$ & $4.0 \%$ & $14.6 \%$ \\
\hline Philippines & $44.7 \%$ & $18.9 \%$ & $2.3 \%$ & $18.6 \%$ & $9.2 \%$ & $27.6 \%$ \\
\hline Singapore & $50.8 \%$ & $17.2 \%$ & $5.3 \%$ & $15.1 \%$ & $11.9 \%$ & $22.2 \%$ \\
\hline Thailand & $50.3 \%$ & $24.7 \%$ & $5.5 \%$ & $11.8 \%$ & $10.4 \%$ & $27.5 \%$ \\
\hline Vietnam & $63.3 \%$ & $14.7 \%$ & $9.0 \%$ & $2.3 \%$ & $8.7 \%$ & $25.6 \%$ \\
\hline Average & $54.8 \%$ & $14.2 \%$ & $7.3 \%$ & $10.5 \%$ & $10.2 \%$ & $24.5 \%$ \\
\hline 2004 & ASEAN10+3 & Japan & China & United States & EU & $\begin{array}{c}\text { rest of the } \\
\text { world }\end{array}$ \\
\hline Brunei Darussalam & $\overline{72.6 \%}$ & 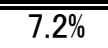 & $3.1 \%$ & $3.3 \%$ & "15.5\% & $8.6 \%$ \\
\hline Cambodia & $69.2 \%$ & $2.5 \%$ & $13.6 \%$ & $1.8 \%$ & $4.2 \%$ & $24.7 \%$ \\
\hline China,P.R.: Mainland & $39.1 \%$ & $16.8 \%$ & - & $8.0 \%$ & $12.5 \%$ & $40.4 \%$ \\
\hline Indonesia & $50.8 \%$ & $13.1 \%$ & $8.8 \%$ & $7.0 \%$ & $11.4 \%$ & $30.8 \%$ \\
\hline Japan & $40.4 \%$ & - & $20.7 \%$ & $14.0 \%$ & $12.7 \%$ & $32.9 \%$ \\
\hline South Korea & $43.7 \%$ & $20.6 \%$ & $13.2 \%$ & $12.9 \%$ & $10.8 \%$ & $32.6 \%$ \\
\hline Lao People's Dem.Rer & $84.9 \%$ & $1.5 \%$ & $10.3 \%$ & $0.6 \%$ & $8.0 \%$ & $6.5 \%$ \\
\hline Malaysia & $55.2 \%$ & $16.1 \%$ & $9.9 \%$ & $14.6 \%$ & $12.1 \%$ & $18.1 \%$ \\
\hline Myanmar & $85.8 \%$ & $3.4 \%$ & $29.8 \%$ & $0.4 \%$ & $3.1 \%$ & $10.7 \%$ \\
\hline Philippines & $48.7 \%$ & $17.4 \%$ & $6.0 \%$ & $18.8 \%$ & $8.3 \%$ & $24.2 \%$ \\
\hline Singapore & $48.9 \%$ & $11.7 \%$ & $9.9 \%$ & $12.7 \%$ & $13.5 \%$ & $24.8 \%$ \\
\hline Thailand & $52.6 \%$ & $23.6 \%$ & $8.6 \%$ & $7.6 \%$ & $9.9 \%$ & $29.9 \%$ \\
\hline Vietnam & $60.4 \%$ & $10.5 \%$ & $13.7 \%$ & $3.8 \%$ & $9.2 \%$ & $26.6 \%$ \\
\hline Average & $57.9 \%$ & $12.0 \%$ & $12.3 \%$ & $8.1 \%$ & $10.1 \%$ & $23.9 \%$ \\
\hline
\end{tabular}

Source: DOTS of IMF (Nov. 2005)

ASEAN 10+ 3 includes ASEAN 10 countries plus South Korea, China and Japan. 
Table 4.

Trade weight of East Asian countries (Exports+Imports)

\begin{tabular}{|c|c|c|c|c|c|c|}
\hline 2000 & ASEAN10+3 & Japan & China & United States & EU & $\begin{array}{c}\text { rest of the } \\
\text { world }\end{array}$ \\
\hline Brunei Darussalam & $\overline{74.2 \%}$ & $29.5 \%$ & $1.6 \%$ & $\overline{111.6 \%}$ & 7.4\% & $6.8 \%$ \\
\hline Cambodia & $35.9 \%$ & $2.7 \%$ & $5.4 \%$ & $30.3 \%$ & $12.8 \%$ & $21.0 \%$ \\
\hline China,P.R.: Mainland & $33.1 \%$ & $17.5 \%$ & - & $15.7 \%$ & $15.1 \%$ & $36.1 \%$ \\
\hline Indonesia & $50.6 \%$ & $20.7 \%$ & $5.0 \%$ & $12.4 \%$ & $13.7 \%$ & $23.3 \%$ \\
\hline Japan & $30.9 \%$ & - & $10.0 \%$ & $25.2 \%$ & $14.9 \%$ & $28.9 \%$ \\
\hline South Korea & $36.7 \%$ & $15.7 \%$ & $9.4 \%$ & $20.2 \%$ & $12.3 \%$ & $30.8 \%$ \\
\hline Lao People's Dem.Rer & $72.8 \%$ & $3.2 \%$ & $4.0 \%$ & $1.3 \%$ & $13.6 \%$ & $12.3 \%$ \\
\hline Malaysia & $49.4 \%$ & $16.7 \%$ & $3.5 \%$ & $18.8 \%$ & $12.6 \%$ & $19.2 \%$ \\
\hline Myanmar & $62.2 \%$ & $6.5 \%$ & $13.1 \%$ & $9.2 \%$ & $9.0 \%$ & $19.6 \%$ \\
\hline Philippines & $39.7 \%$ & $16.7 \%$ & $2.0 \%$ & $24.5 \%$ & $13.9 \%$ & $21.9 \%$ \\
\hline Singapore & $46.5 \%$ & $12.3 \%$ & $4.6 \%$ & $16.2 \%$ & $13.0 \%$ & $24.3 \%$ \\
\hline Thailand & $44.9 \%$ & $19.5 \%$ & $4.7 \%$ & $16.8 \%$ & $13.5 \%$ & $24.8 \%$ \\
\hline Vietnam & $56.4 \%$ & $16.2 \%$ & $9.8 \%$ & $3.6 \%$ & $14.4 \%$ & $25.5 \%$ \\
\hline Average & $48.7 \%$ & $14.8 \%$ & $6.1 \%$ & $15.8 \%$ & $12.8 \%$ & $22.7 \%$ \\
\hline 2004 & ASEAN10+3 & Japan & China & United States & EU & $\begin{array}{c}\text { rest of the } \\
\text { world }\end{array}$ \\
\hline Brunei Darussalam & $73.6 \%$ & $29.9 \%$ & $4.1 \%$ & $7.2 \%$ & $6.0 \%$ & $13.2 \%$ \\
\hline Cambodia & $45.2 \%$ & $2.9 \%$ & $8.3 \%$ & $24.7 \%$ & $13.4 \%$ & $16.8 \%$ \\
\hline China,P.R.: Mainland & $31.5 \%$ & $14.5 \%$ & - & $14.7 \%$ & $15.4 \%$ & $38.4 \%$ \\
\hline Indonesia & $52.5 \%$ & $18.7 \%$ & $7.4 \%$ & $10.2 \%$ & $12.2 \%$ & $25.1 \%$ \\
\hline Japan & $36.7 \%$ & - & $16.5 \%$ & $18.8 \%$ & $14.4 \%$ & $30.0 \%$ \\
\hline South Korea & $40.5 \%$ & $14.2 \%$ & $16.6 \%$ & $15.1 \%$ & $13.0 \%$ & $31.4 \%$ \\
\hline Lao People's Dem.Rer & $68.5 \%$ & $1.4 \%$ & $7.5 \%$ & $0.6 \%$ & $15.0 \%$ & $15.9 \%$ \\
\hline Malaysia & $49.8 \%$ & $12.8 \%$ & $8.1 \%$ & $16.9 \%$ & $12.4 \%$ & $20.9 \%$ \\
\hline Myanmar & $71.9 \%$ & $4.3 \%$ & $18.5 \%$ & $0.2 \%$ & $9.3 \%$ & $18.6 \%$ \\
\hline Philippines & $47.8 \%$ & $18.7 \%$ & $6.3 \%$ & $18.5 \%$ & $12.5 \%$ & $21.2 \%$ \\
\hline Singapore & $46.1 \%$ & $9.0 \%$ & $9.2 \%$ & $12.9 \%$ & $14.0 \%$ & $27.1 \%$ \\
\hline Thailand & $48.6 \%$ & $18.7 \%$ & $7.9 \%$ & $11.8 \%$ & $12.3 \%$ & $27.2 \%$ \\
\hline Vietnam & $50.7 \%$ & $11.9 \%$ & $11.7 \%$ & $11.0 \%$ & $15.5 \%$ & $22.9 \%$ \\
\hline Average & $51.0 \%$ & $13.1 \%$ & $10.2 \%$ & $12.5 \%$ & $12.7 \%$ & $23.7 \%$ \\
\hline
\end{tabular}

Source: DOTS of IMF (Nov. 2005)

ASEAN 10+ 3 includes ASEAN 10 countries plus South Korea, China and Japan. 
Table 5.

The linkages of East Asian currencies with three major currencies (2004)

\begin{tabular}{|c|c|c|c|c|c|c|c|}
\hline & US dollar & & euro & \multicolumn{3}{|c|}{ Japanese yen } & Adj. R2 \\
\hline Chinese yuan & $\begin{array}{c}1.0003 \\
(0.0002)\end{array}$ & $* * *$ & $\begin{array}{l}-0.0004 \\
(0.0006)\end{array}$ & & $\begin{array}{l}-0.0001 \\
(0.0002)\end{array}$ & & 0.9999 \\
\hline Singapore dollar & $\begin{array}{l}0.5787 \\
(0.0229)\end{array}$ & $* * *$ & $\begin{array}{c}0.1603 \\
(0.0622)\end{array}$ & $* *$ & $\begin{array}{c}0.2729 \\
(0.0208)\end{array}$ & $* * *$ & 0.9095 \\
\hline Thai baht & $\begin{array}{l}0.7272 \\
(0.0273)\end{array}$ & $* * *$ & $\begin{array}{c}0.1920 \\
(0.0741)\end{array}$ & $* *$ & $\begin{array}{c}0.1923 \\
(0.0248)\end{array}$ & $* * *$ & 0.8962 \\
\hline Malaysian ringgit & $\begin{array}{c}1.0046 \\
(0.0026)\end{array}$ & $* * *$ & $\begin{array}{c}0.0001 \\
(0.0070)\end{array}$ & & $\begin{array}{c}-0.0035 \\
(0.0023)\end{array}$ & & 0.9992 \\
\hline Philippine peso & $\begin{array}{l}0.9101 \\
(0.0230)\end{array}$ & $* * *$ & $\begin{array}{c}0.0004 \\
(0.0624)\end{array}$ & & $\begin{array}{c}0.0661 \\
(0.0208)\end{array}$ & $* * *$ & 0.9323 \\
\hline Indonesian rupiah & $\begin{array}{l}0.7445 \\
(0.0631)\end{array}$ & $* * *$ & $\begin{array}{c}0.1309 \\
(0.1714)\end{array}$ & & $\begin{array}{c}0.1973 \\
(0.0573)\end{array}$ & $* * *$ & 0.6216 \\
\hline South Korean won & $\begin{array}{l}0.7557 \\
(0.0454)\end{array}$ & $* * *$ & $\begin{array}{c}0.2412 \\
(0.1233)\end{array}$ & $*$ & $\begin{array}{c}0.1905 \\
(0.0412)\end{array}$ & $* * *$ & 0.7706 \\
\hline Burunei dollar & $\begin{array}{l}0.6087 \\
(0.0250)\end{array}$ & $* * *$ & $\begin{array}{c}0.2692 \\
(0.0679)\end{array}$ & $* * *$ & $\begin{array}{c}0.1911 \\
(0.0227)\end{array}$ & $* * *$ & 0.8893 \\
\hline Cambodia riel & $\begin{array}{l}0.9953 \\
(0.0316)\end{array}$ & $* * *$ & $\begin{array}{c}0.0715 \\
(0.0858)\end{array}$ & & $\begin{array}{c}0.0018 \\
(0.0287)\end{array}$ & & 0.8899 \\
\hline Laos kip & $\begin{array}{l}0.9844 \\
(0.0134)\end{array}$ & $* * *$ & $\begin{array}{c}-0.0158 \\
(0.0364)\end{array}$ & & $\begin{array}{c}-0.0009 \\
(0.0122)\end{array}$ & & 0.9771 \\
\hline Myanmar kyat & $\begin{array}{l}0.9872 \\
(0.0101)\end{array}$ & $* * *$ & $\begin{array}{c}-0.0095 \\
(0.0275)\end{array}$ & & $\begin{array}{c}0.0095 \\
(0.0092)\end{array}$ & & 0.9871 \\
\hline Vietnamese dong & $\begin{array}{l}0.9968 \\
(0.0056)\end{array}$ & $* * *$ & $\begin{array}{c}-0.0199 \\
(0.0151)\end{array}$ & & $\begin{array}{c}0.0036 \\
(0.0051)\end{array}$ & & 0.9961 \\
\hline
\end{tabular}

Calculated by authors. All exchange data are from Datastream.

1. We estimated weights on the US dollar, the euro and the Japanese yen in a possible currency basket for some East Asian countries according to a method of Frankel and Wei (1994). We use the Swiss francs as a numeraire currency.

2. Standard errors are in parenthesis. * ** and $* * *$ denote statistical significance at the $10 \%$, $5 \%$ and $1 \%$ levels, respectively. 
Table 6.

The linkages of East Asian currencies with three major currencies (2005)

\begin{tabular}{|c|c|c|c|c|c|c|c|}
\hline & US dollar & & euro & & Japanese yer & & Adj. R2 \\
\hline Chinese yuan & $\begin{array}{c}0.9213 \\
(0.01974)\end{array}$ & $* * *$ & $\begin{array}{c}0.0412 \\
(0.06141)\end{array}$ & & $\begin{array}{c}0.0935 \\
(0.02100)\end{array}$ & $* * *$ & 0.9576 \\
\hline Singapore dollar & $\begin{array}{l}0.5021 \\
(0.0271)\end{array}$ & $* * *$ & $\begin{array}{c}0.1707 \\
(0.0844)\end{array}$ & ** & $\begin{array}{c}0.3926 \\
(0.0289)\end{array}$ & $* * *$ & 0.8817 \\
\hline Thai baht & $\begin{array}{c}0.6182 \\
(0.0374)\end{array}$ & $* * *$ & $\begin{array}{c}0.1301 \\
(0.1163)\end{array}$ & & $\begin{array}{c}0.3124 \\
(0.0398)\end{array}$ & *** & 0.8163 \\
\hline Malaysian ringgit & $\begin{array}{l}0.9869 \\
(0.0252)\end{array}$ & $* * *$ & $\begin{array}{c}0.0228 \\
(0.0784)\end{array}$ & & $\begin{array}{c}-0.0124 \\
(0.0268)\end{array}$ & & 0.9337 \\
\hline Philippine peso & $\begin{array}{l}0.8428 \\
(0.0374)\end{array}$ & $* * *$ & $\begin{array}{c}0.0727 \\
(0.1162)\end{array}$ & & $\begin{array}{c}0.1178 \\
(0.0397)\end{array}$ & $* * *$ & 0.8473 \\
\hline Indonesian rupiah & $\begin{array}{l}0.6728 \\
(0.1161)\end{array}$ & $* * *$ & $\begin{array}{c}0.0910 \\
(0.3614)\end{array}$ & & $\begin{array}{c}0.2305 \\
(0.1236)\end{array}$ & * & 0.3075 \\
\hline South Korean won & $\begin{array}{l}0.5597 \\
(0.0594)\end{array}$ & $* * *$ & $\begin{array}{c}0.2179 \\
(0.1847)\end{array}$ & & $\begin{array}{c}0.2169 \\
(0.0632)\end{array}$ & $* * *$ & 0.5715 \\
\hline Burunei dollar & $\begin{array}{l}0.5264 \\
(0.0295)\end{array}$ & $* * *$ & $\begin{array}{c}0.1619 \\
(0.0917)\end{array}$ & * & $\begin{array}{c}0.2931 \\
(0.0314)\end{array}$ & $* * *$ & 0.8480 \\
\hline Cambodia riel & $\begin{array}{l}0.9255 \\
(0.0692)\end{array}$ & $* * *$ & $\begin{array}{c}0.2195 \\
(0.2154)\end{array}$ & & $\begin{array}{c}-0.0242 \\
(0.0737)\end{array}$ & & 0.6309 \\
\hline Laos kip & $\begin{array}{c}0.6751 \\
(0.2962)\end{array}$ & $* *$ & $\begin{array}{c}-1.1907 \\
(0.9216)\end{array}$ & & $\begin{array}{c}0.2262 \\
(0.3151)\end{array}$ & & 0.0359 \\
\hline Myanmar kyat & $\begin{array}{c}0.9437 \\
(0.0268)\end{array}$ & $* * *$ & $\begin{array}{c}0.0973 \\
(0.0833)\end{array}$ & & $\begin{array}{c}-0.0214 \\
(0.0285)\end{array}$ & & 0.9202 \\
\hline Vietnamese dong & $\begin{array}{c}0.9944 \\
(0.0062)\end{array}$ & $* * *$ & $\begin{array}{l}-0.0158 \\
(0.0193)\end{array}$ & & $\begin{array}{c}0.0057 \\
(0.0066) \\
\end{array}$ & & 0.9958 \\
\hline
\end{tabular}

Calculated by authors. All exchange data are from Datastream. We use the data by 30 Nov, 2005. 1. We estimated weights on the US dollar, the euro and the Japanese yen in a possible currency basket for some East Asian countries according to a method of Frankel and Wei (1994). We use the Swiss francs as a numeraire currency.

2. Standard errors are in parenthesis. * *** and $* * *$ denote statistical significance at the $10 \%$, $5 \%$ and $1 \%$ levels, respectively. 
Table 7.

Trade Accounts of ASEAN $10+3$ (Japan, South Korea and China) millions of US\$

\begin{tabular}{cccc}
\hline & with Japan* & within ASEAN+3 & with World \\
\hline \hline 1990 & $-23,437$ & $-1,695$ & 35,851 \\
1991 & $-33,084$ & $-4,666$ & 58,013 \\
1992 & $-41,172$ & -811 & 91,249 \\
1993 & $-54,184$ & $-4,940$ & 89,923 \\
1994 & $-65,089$ & 9,572 & 105,815 \\
1995 & $-73,856$ & 14,672 & 82,362 \\
1996 & $-59,680$ & 12,278 & 26,041 \\
1997 & $-54,531$ & 26,484 & 103,764 \\
1998 & $-29,802$ & 12,131 & 242,064 \\
1999 & $-32,065$ & 4,819 & 221,181 \\
2000 & $-37,239$ & $-6,562$ & 191,768 \\
2001 & $-23,997$ & 1,953 & 134,520 \\
2002 & $-40,027$ & 12,289 & 168,690 \\
2003 & $-55,724$ & 27,727 & 196,539 \\
\hline
\end{tabular}

Notes: All figures are calculated by authors. Trade data are from DOTS (IMF) and GDP data are from IFS (IMF).

* The figure of trade account with Japan is the total amount of trade accounts with 12 East Asian countries. 
Table 8.

AMU weights of East Asian Currencies (benchmark year=2000/2001)

\begin{tabular}{cccccc}
\hline & Trade volume* \% & $\begin{array}{c}\text { GDP measured at } \\
\text { PPP** } \%\end{array}$ & $\begin{array}{c}\text { Arithmetical } \\
\text { average of share \% } \\
(\mathrm{a})\end{array}$ & $\begin{array}{c}\text { Benchmark } \\
\text { exchange rate*** } \\
(\mathrm{b})\end{array}$ & $\begin{array}{c}\text { AMU weights } \\
(\mathrm{a}) /(\mathrm{b})\end{array}$ \\
\hline \hline Brunei & 0.41 & 0.41 & 0.41 & 0.5912 & 0.0069 \\
Cambodia & 0.19 & 0.21 & 0.20 & 0.0003 & 7.4235 \\
China & 21.65 & 47.93 & 34.79 & 0.1256 & 2.7711 \\
Indonesia & 4.67 & 5.56 & 5.12 & 0.0001 & 452.7871 \\
Japan & 27.31 & 28.30 & 27.80 & 0.0091 & 30.5681 \\
South Korea & 12.86 & 6.65 & 9.76 & 0.0009 & 113.1459 \\
Laos & 0.09 & 0.08 & 0.08 & 0.0001 & 5.9500 \\
Malaysia & 8.85 & 1.83 & 5.34 & 0.2735 & 0.1953 \\
Myanmar & 0.38 & 0.38 & 0.38 & 0.1598 & 0.0239 \\
Philippines & 3.12 & 2.74 & 2.93 & 0.0220 & 1.3347 \\
Singapore & 11.90 & 0.81 & 6.36 & 0.5912 & 0.1075 \\
Thailand & 6.60 & 3.56 & 5.08 & 0.0246 & 2.0630 \\
Vietnam & 1.96 & 1.53 & 1.74 & 0.0001 & 243.0432 \\
\hline
\end{tabular}

*: The trade volume is calculated as an average of total export and import volumes in 2001, 2002 and 2003 from DOTS (IMF).

**: GDP measured at PPP is the average of GDP measured at PPP in 2001, 2002 and 2003 from the World Development Report, World Bank. For Brunei and Myanmar, we use same share of trade volume since there are no GDP data for Brunei and Myanmar.

***: Benchmark exchange rate (\$-euro/Currency) is the average of daily exchange rate in terms of \$-euro in 2000 and 2001. 
Table 9.

Basket weights for 7 East Asian currencies (percent)

\begin{tabular}{|c|c|c|c|c|c|c|}
\hline \multirow{2}{*}{ Country } & \multicolumn{2}{|c|}{ Own basket } & \multicolumn{2}{|c|}{$\begin{array}{c}\text { Common basket } \\
\text { (G3) }\end{array}$} & \multicolumn{2}{|c|}{$\begin{array}{c}\text { Common basket } \\
\text { (AMU) }\end{array}$} \\
\hline & US dollar & 25.1 & US dollar & 40.2 & & \\
\hline & euro & 20.9 & euro & 31.6 & & \\
\hline & Yen & 22.9 & Yen & 28.2 & & \\
\hline & HK dollar & 19.3 & & & & \\
\hline & Won & 11.8 & & & & \\
\hline \multirow[t]{8}{*}{ Indonesia } & US dollar & 14.9 & US dollar & 40.2 & & \\
\hline & euro & 16.1 & euro & 31.6 & & \\
\hline & Yen & 29.7 & Yen & 28.2 & & \\
\hline & RMB & 12.8 & & & & \\
\hline & MYR & 7.9 & & & & \\
\hline & Sing. dollar & 11.6 & & & & \\
\hline & Won & 7.0 & & & Brunei & 0.4 \\
\hline & & & & & Cambodia & 0.2 \\
\hline \multirow[t]{7}{*}{ Malaysia } & US dollar & 25.8 & US dollar & 40.2 & China & 34.8 \\
\hline & euro & 15.0 & euro & 31.6 & Indonesia & 5.1 \\
\hline & Yen & 19.5 & Yen & 28.2 & Japan & 27.8 \\
\hline & RMB & 12.4 & & & South Korea & 9.8 \\
\hline & HK dollar & 6.9 & & & Laos & 0.1 \\
\hline & Sing. dollar & 20.3 & & & Malaysia & 5.3 \\
\hline & & & & & Myanmar & 0.4 \\
\hline \multirow[t]{7}{*}{ Philippines } & US dollar & 22.5 & US dollar & 40.2 & Philippines & 2.9 \\
\hline & euro & 13.8 & euro & 31.6 & Singapore & 6.4 \\
\hline & Yen & 24.5 & Yen & 28.2 & Thailand & 5.1 \\
\hline & RMB & 12.6 & & & Vietnam & 1.7 \\
\hline & HK dollar & 9.1 & & & & \\
\hline & MYR & 6.6 & & & & \\
\hline & Sing. dollar & 10.9 & & & & \\
\hline \multirow[t]{5}{*}{ Singapore } & US dollar & 22.5 & US dollar & 40.2 & & \\
\hline & euro & 19.0 & euro & 31.6 & & \\
\hline & Yen & 15.7 & Yen & 28.2 & & \\
\hline & RMB & 16.2 & & & & \\
\hline & MYR & 26.7 & & & & \\
\hline \multirow[t]{4}{*}{ South Korea } & US dollar & 26.6 & US dollar & 40.2 & & \\
\hline & euro & 17.6 & euro & 31.6 & & \\
\hline & Yen & 25.4 & Yen & 28.2 & & \\
\hline & RMB & 30.4 & & & & \\
\hline \multirow[t]{6}{*}{ Thailand } & US dollar & 19.9 & US dollar & 40.2 & & \\
\hline & euro & 16.0 & euro & 31.6 & & \\
\hline & Yen & 31.5 & Yen & 28.2 & & \\
\hline & RMB & 13.4 & & & & \\
\hline & MYR & 9.5 & & & & \\
\hline & Sing. dollar & 9.8 & & & & \\
\hline
\end{tabular}

Own basket and Common basket (G3) are from Williamson (2005). Common basket (AMU) are calculated by authors.

Source: DOTS, May 2005 (IMF). 
Table 10.

Standard deviation of East Asian nominal effective exchange rates under different pegs, 2000-2004

\begin{tabular}{|c|c|c|c|c|c|c|}
\hline \multirow{2}{*}{ Country } & \multirow{2}{*}{$\begin{array}{l}\text { (1) Actual historical } \\
\text { experience }\end{array}$} & \multirow{2}{*}{$\begin{array}{l}\text { (2) Individual-country } \\
\text { peg }\end{array}$} & \multirow{2}{*}{$\begin{array}{l}\text { (3) Common basket } \\
\text { (G3) peg }\end{array}$} & \multicolumn{3}{|c|}{ (4) Common basket (AMU) peg } \\
\hline & & & & own country only & within ASEAN & within ASEAN+3 \\
\hline China & 5.21 & 3.49 & 1.58 & 3.50 & 3.50 & 3.09 \\
\hline Indonesia & 6.35 & 5.61 & 3.85 & 2.16 & 2.15 & 1.78 \\
\hline Malaysia & 5.29 & 2.77 & 1.58 & 2.23 & 2.04 & 1.94 \\
\hline Philippines & 9.55 & 12.68 & 5.41 & 2.13 & 2.07 & 1.89 \\
\hline Singapore & 2.54 & 1.62 & 1.25 & 2.34 & 2.18 & 2.10 \\
\hline South Korea & 3.32 & 4.42 & 2.01 & 2.11 & 2.11 & 1.97 \\
\hline Thailand & 2.92 & 3.87 & 1.90 & 2.07 & 2.05 & 1.77 \\
\hline
\end{tabular}

The results of (1)(2)(3) are from Williamson (2005) and (4) are calculated by authors.

(1) Standard deviations of period end monthly nominal effective exchange rates are from IFS, May 2005 (IMF). Data for Indonesia are from Thomson Datastream Series JPMIDNB. Data for South Korea and Thailand real effective exchange rates are from the Citibank CTERI database (January 2000=100).

(2) Nominal effective exchange rates(NEER) with individual-country pegs are calculated as follows: The weights shown in table9, column 1,were used to calculate what the dollar exchange rate $(\mathrm{LCU} / \$)$ would have been. Actual exchange rates against the dollar were used to derive other hypothetical rates. These were combined with the trade weights to estimate a hypothetical time path for the NEER. The standard deviation of that path is reported in the table. All bilateral exchange rates are set at January $2000=100$.

(3) Common basket pegs composed by G3 currencies are calculated using 1999 as the base year $(\$ 1=0.9363$ euro and $\$ 1=113.91)$, with the weights of dollar, euro and yen composition of $40.2,31.6$, and 28.2 respectively. From these, the LCU/\$, euro, and $¥$ implied by the basket composition and dollar/euro/yen exchange rates are calculated. These are weighted by the individual-country trade weights to yield the NEERs with the common basket peg. All bilateral exchange rates are set at January $2000=100$.

(4) Common basket pegs (AMU) composed by ASEAN+3 currencies are calculated using 2000 and 2001 as the base year. From these, the US $\$$, euro, $¥$ and East Asian currencies in terms of AMU are calculated. These are weighted by the individual-country trade weights to yield the NEERs with the AMU peg. There are three different types of AMU peg. First is the case in which own country only applies the AMU peg. Second is the case in which AMU pegs are applied within ASEAN countries. Third is the case in which the AMU pegs are applied within ASEAN +3 countries. All bilateral exchange rates are set at January $2000=100$. 
Figure 1.

The Nominal Exchange Rates vis-a-vis the US dollar (Jan 2000-Oct 2005)

\begin{tabular}{|c|c|c|c|c|c|}
\hline $2000=100$ & $\begin{array}{l}\text { - Brunei\$ } \\
\text { - South Korean won } \\
\text { Singapore\$ }\end{array}$ & $\begin{array}{l}\text { - Cambodia riel } \\
\text { - Laos kip } \\
\text { Thai baht }\end{array}$ & $\begin{array}{l}\text { Chinese ynan } \\
- \text { Malaysian ringgit } \\
\text { Vietnamese dong }\end{array}$ & $\begin{array}{l}\text { - Indonesian rupiah } \\
\text { - Myanmar kyat }\end{array}$ & $\begin{array}{l}\text { - Japanese yen } \\
\text { Philippine peso }\end{array}$ \\
\hline
\end{tabular}

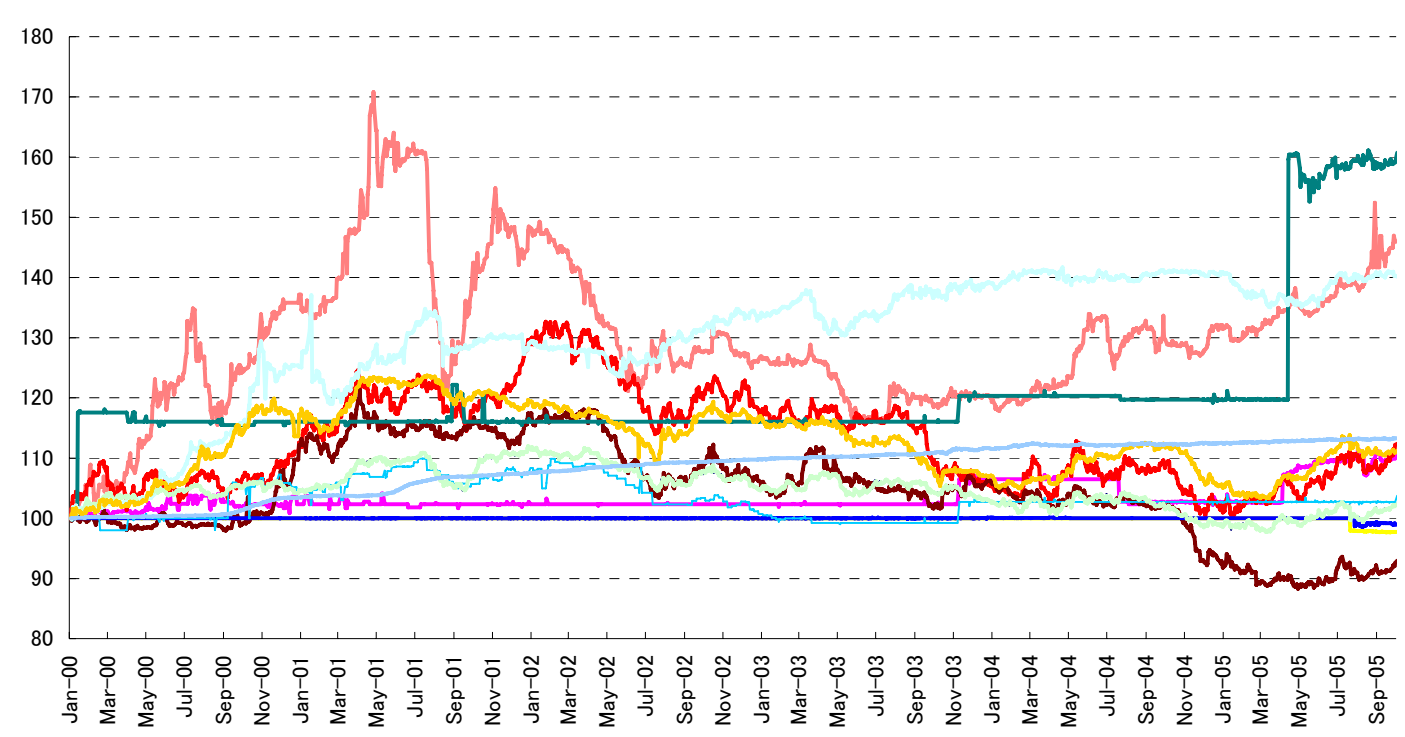

Figure 2.

The Nominal Exchange Rates vis-a-vis the Japanese yen (Jan 2000-Oct 2005)

\begin{tabular}{|c|c|c|c|c|}
\hline $\begin{array}{l}\text { Brunei\$ } \\
\text { Malaysian ringgit }\end{array}$ & $\begin{array}{l}\text { - Cambodia riel } \\
\text { Myanmar kyat }\end{array}$ & $\begin{array}{l}\text { Chinese ynan } \\
\text { Philippine peso }\end{array}$ & $\begin{array}{l}\text { Indonesian rupiah } \\
\text { Singapore } \$\end{array}$ & $\begin{array}{l}\text { - South Korean won }- \text { Laos kip } \\
\text { Thai baht } \quad \text { Vietnamese dong }\end{array}$ \\
\hline
\end{tabular}

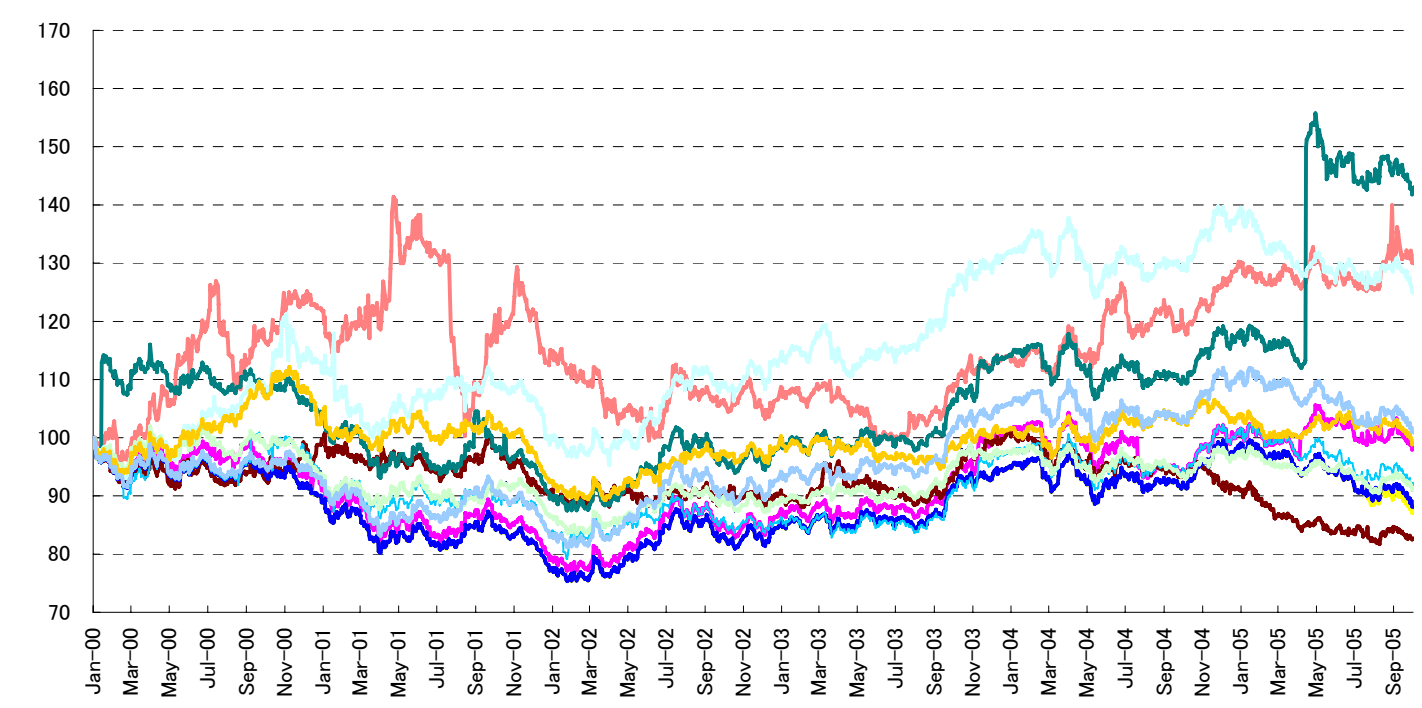


Figure 3.

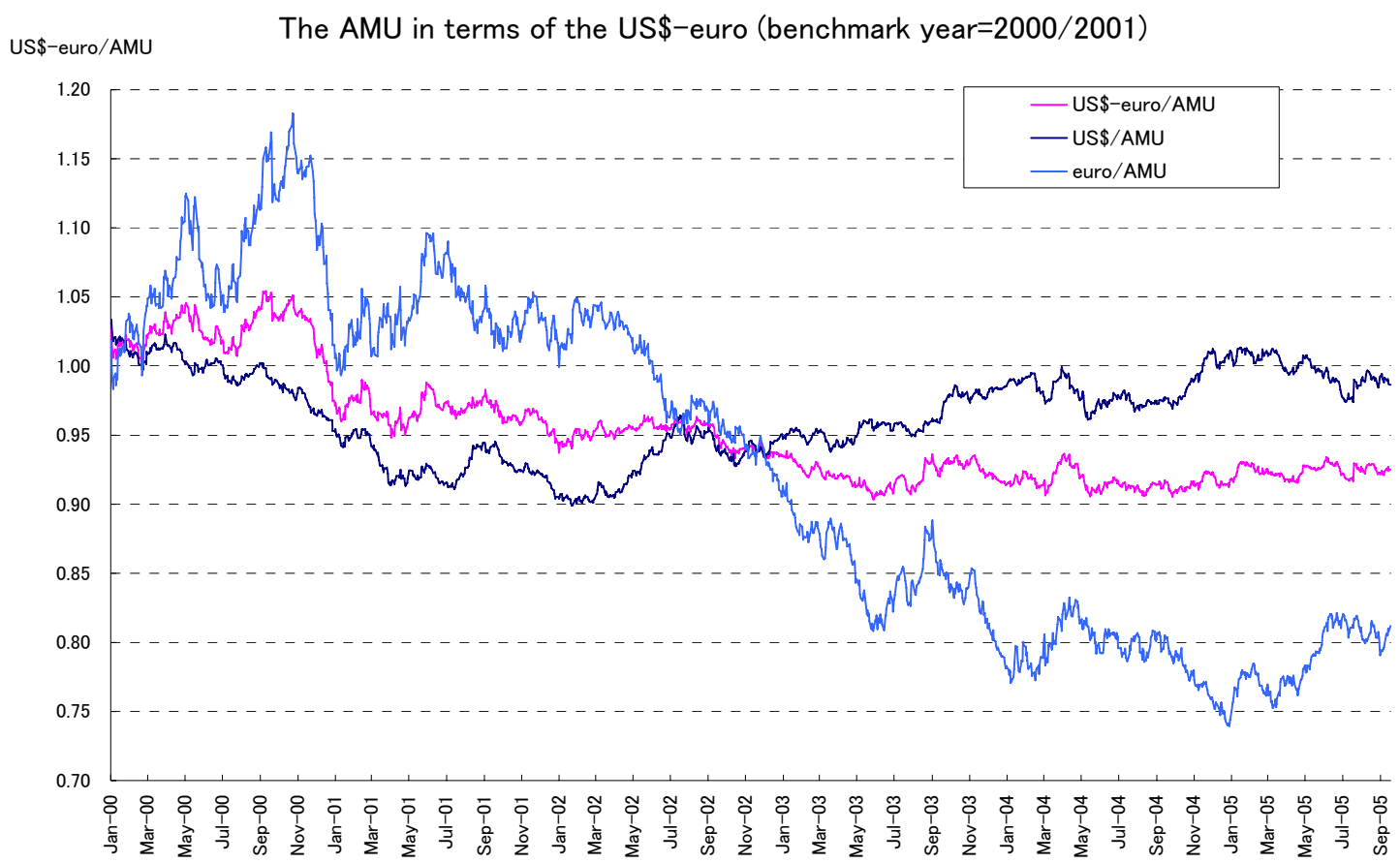

Figure 4.

The Nominal Exchange Rates vis-a-vis the AMU (Jan 2000-Oct 2005)

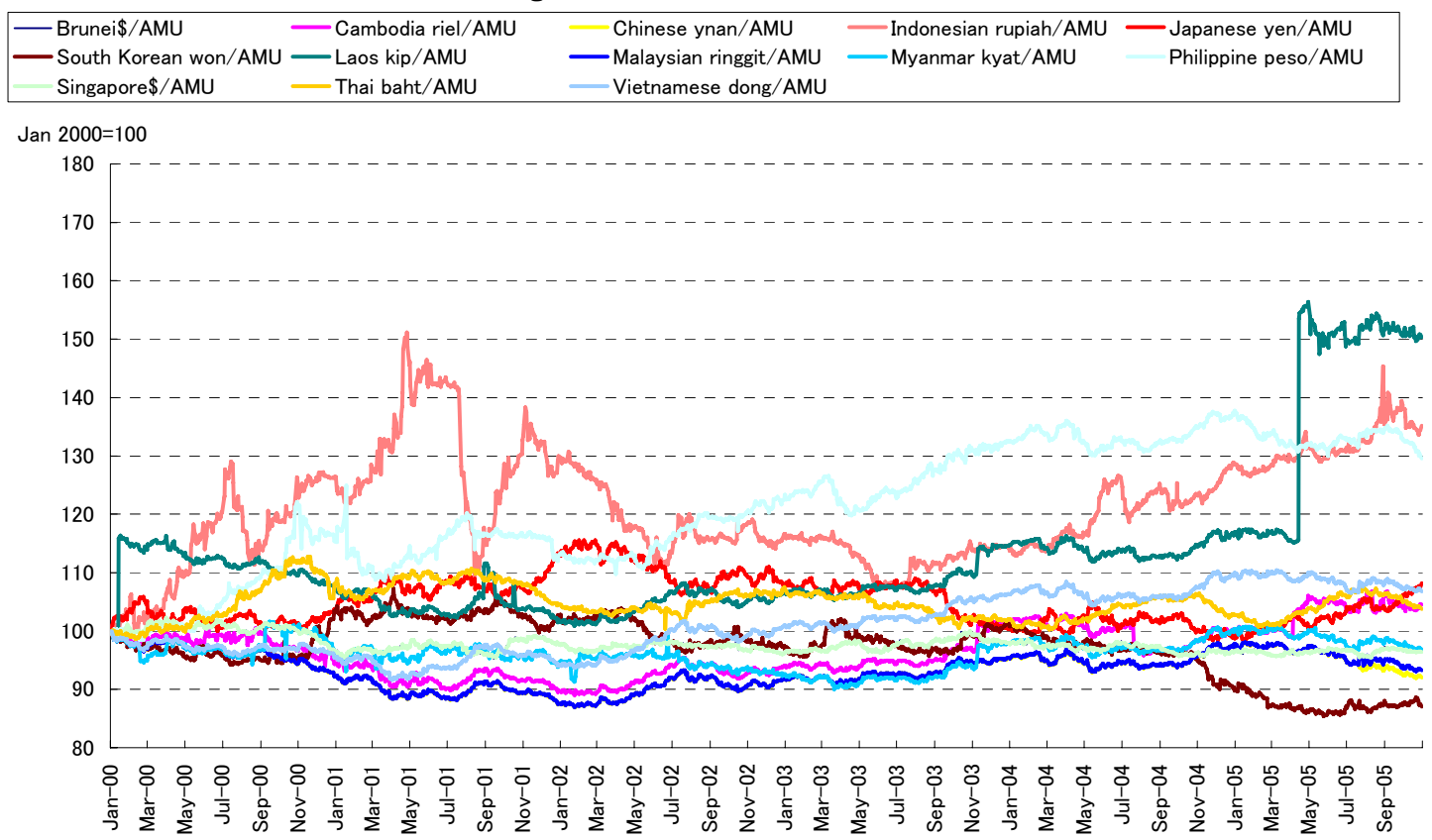

